\title{
Transparency, accountability and empowerment in sustainability governance: a conceptual review
}

\author{
Michael Mason
}

\begin{abstract}
This paper offers a conceptual examination of the power-effects of transparency, as information disclosure, on those making accountability claims against actors deemed to be causing significant environmental harm. Informed by Lukes's (2005) multi-dimensional theory of power, I review recent scholarship to interrogate four hypotheses positing empowerment for accountability claimants arising from the disclosure of sustainability information. Across public and private governance forms, academic research suggests that information disclosure promotes the communication of the sustainability interests of affected parties, and in some cases enhances the capacity of these parties to evaluate justifications provided by relevant power-wielders. However, evidence is weaker that disclosure of sustainability information empowers accountability claimants to sanction or otherwise steer those responsible; and there is little support that transparency fosters wider political interrogation of the configurations of authority producing environmental harm.

Differentiating between behavioural and non-behavioural understandings of power allows an evaluation of these research findings on the power-related effects of information disclosure.
\end{abstract}

Keywords: transparency, accountability, power, sustainability, governance 


\section{Introduction}

In what ways does transparency, understood here as information disclosure, empower those seeking accountability for actions causing significant environmental harm? It has become a maxim of "governance by disclosure" (Gupta, 2008: Haufler, 2010; Stephan, 2002) that transparency facilitates empowerment, as applied to multiple scales and issues of sustainability governance. Viewing transparency as a necessary condition of accountability carries transformative assumptions; that those negatively affected have the capability to make a meaningful political claim for answerability and redress. Whether these claims are relayed directly to those held responsible or communicated to a governing authority, the expectation is that information disclosure assists in the political mobilisation of affected parties, leaving scholarship to examine the institutional practices impeding or promoting accountability in relevant issue areas. However, largely unexamined are the different ways in which the powereffects attributed to the disclosure of sustainability information connect to accountability claim-making.

This paper offers a conceptual examination of the power-effects of information disclosure for those engaged in accountability claims against actors deemed to be causing significant environmental harm. In what ways, and to what extent, do different practices of disclosure displace, replace or replicate power differentials in relationships of accountability? The theoretical point of departure is Steven Lukes's (2005) multi-dimensional view of power as a capacity to secure a state of affairs, which encompasses both influence over (non)decisionmaking and a less overt, systemic capacity to produce outcomes favourable to the powerful without the need for coercive interventions (2005, p.28). This conceptual framing accounts for situations in which particular vectors of empowerment in a governance domain may in fact co-exist with disempowering effects on a wider transformative politics. While the paper reviews a range of empirical studies investigating the nexus of transparency, accountability 
and (environmental) sustainability, its principal aim is to offer an analytical understanding of how transparency relates to accountability claim-making in sustainability governance.

I next provide a brief summary of the main conceptual perspectives on transparency-led accountability in sustainability governance, identifying from this literature four hypotheses positing different power-effects for accountability claimants arising from the disclosure of sustainability information: these hypotheses are differentiated below according to behavioural and non-behavioural understandings of power, as categorised by Lukes. This conceptual discussion is followed by a review of recent scholarship (drawing on a bibliographic search of academic publications since 2001) concerned with the functioning of information disclosure in sustainability governance, differentiated according to whether public or private actors are the principal loci of governing authority. The conclusion summarises findings on the four hypotheses as they relate to a multi-dimensional theory of power.

\section{Information disclosure and empowerment in sustainability governance}

Disclosure-led claims for accountability are one subset of what has been labelled a transparency turn in sustainability governance, encompassing diverse trajectories of information flowing from and to a wide range of state and non-state actors (Gupta \& Mason, 2014; Kraft et al., 2011; Mol, 2007). The connections between transparency and accountability are complex in this governance domain (Biermann, 2014, p.123; Kramarz and Park, 2016): if we accept a broad definition of sustainability as involving responsibility for actions affecting future people (Norton, 2005, p.304), the sustainability goals which may be addressed by disclosure-led accountability are multiple - inter alia economic efficiency, environmental effectiveness, social equity, and resilience - and may or may not be internally coherent depending on particular applications. Despite this value multiplicity, since the 1990s 
there has been a growing uptake of information disclosure as a regulatory choice for furthering sustainability, evident in such widely shared disclosure methods as environmental assessment, pollution and transfer registers, public accessibility of governance meetings, sustainability ratings schemes and social-ecological certification.

Transparency of governance processes is often assumed to be a necessary if not sufficient condition of accountability where accountability is broadly understood as holding authoritative actors both answerable for their actions and also subject to evaluation and redress by those affected by them (Bäckstrand, 2008; Florini, 2007; Grant \& Keohane, 2005). Table 1 lists four hypotheses of empowerment to categorise posited effects of information disclosure on accountability claimants. These hypotheses identify different causal mechanisms of empowerment of accountability claimants arising directly from the disclosure of sustainability information. As noted below, the hypotheses are derived from theoretical accounts of the transparency-accountability nexus in sustainability governance: they are open to rejection to the extent that empirical findings may, in relation to the counterfactual, demonstrate a reduction in power (disempowerment) or no change (i.e. a failure to empower or disempower). The hypotheses also reflect Lukes's (2005) multi-dimensional concept of power, which distinguishes, on the one hand, between power as the capacity of actors to exert control or influence over political-policy decisions (one-dimensional view) and nondecisions (two-dimensional view) and, on the other hand, the capacity to secure domination (thirddimensional view); that is, the ability "to prevent people, to whatever degree, from having grievances by shaping their perceptions, cognitions and preferences in such a way that they accept their role in the existing order of things" (Lukes, 2005, p.11). 


\begin{tabular}{|l|l|}
\hline H1 & $\begin{array}{l}\text { Reducing information asymmetry between a decision maker and affected parties } \\
\text { lowers the information costs of the latter making accountability claims }\end{array}$ \\
\hline H2 & $\begin{array}{l}\text { Information disclosure enhances the capacity of accountability claimants to evaluate } \\
\text { justifications provided by the relevant power-wielder }\end{array}$ \\
\hline H3 & $\begin{array}{l}\text { Information disclosure enhances the capacity of accountability claimants to steer } \\
\text { relevant power-wielders }\end{array}$ \\
\hline H4 & $\begin{array}{l}\text { Information disclosure empowers accountability claimants by fostering political } \\
\text { interrogation of the configurations of decision-making authority producing } \\
\text { environmental harm }\end{array}$ \\
\hline
\end{tabular}

Table 1: Hypotheses positing empowerment of accountability claimants arising directly from the disclosure of sustainability information

The first two hypotheses on empowerment capture the causal claim that disclosure of sustainability information fosters answerability by empowering the capacity of affected parties to represent their interests and to assess justifications provided by decision makers held responsible. Thus, Hypothesis 1 (H1) states that reducing information asymmetry between a decision maker and affected party lowers the information costs of the latter in making their accountability claims, while Hypothesis 2 (H2) states that information disclosure enhances the capacity of accountability claimants to evaluate justifications provided by the relevant power-wielders. Claim-making for answerability is a relational exercise in which transparency only becomes relevant insofar as affected parties use the disclosed information to construct shared sustainability interests and compel wielders of power to justify their decisions. Linguistically, accountability is an illocutionary effect: an actor gives an account of her or his actions according to reasons that may be accepted as 
convincing by those affected (Habermas 1998:310). Whether the justification provided by the power-wielder is accepted as plausible by the affected parties depends on their evaluative capacity as well as the information released, and reasons given, by the responsible party. This is not a static relationship as it is constituted, in principle, by intersubjective, iterative dialogue on accountability open to revision in the light of new evidence and possible mutual understanding.

Over and above answerability for governance decisions with significant sustainability effects, holding to account also implies an ability to change the behaviour of the governance actor responsible for the relevant decision(s), whether in relation to standards set by an existing institutional context and/or other societal norms. Environmental sustainability, as a normative notion, prioritises accountability standards informed by the need to prevent and/or mitigate significant socio-ecological harm. The more the impacts of governance decisions are shown to approach or cross biophysical thresholds, seriously degrading human conditions of life (Rockström et al., 2009; Steffen et al., 2015), the greater the moral legitimacy claimed for sustainability against competing norms and values. Of course, complexity and uncertainty, along with the growing hybridity of governance arrangements, often create major scientific challenges in ascribing responsibility for particular environmental effects. However, in a specific governance context, where accountability claimants credibly reveal involuntary harm caused by the decisions of a public or private actor, we can ask to what extent disclosed information fosters greater compliance of these power wielders, whether through their exposure to sanctions or from an enhanced capacity of affected parties to monitor and call them to account. The aspect of empowerment posited here is expressed by Hypothesis 3 (H3) - information disclosure enhances the capacity of accountability claimants to steer relevant power-wielders. Empirically this requires evaluating the role of disclosure-led accountability claims in altering the behaviour of responsible parties. Moving beyond accountability claim- 
making for particular sustainability-related grievances, Hypothesis $4(\mathrm{H} 4)$ posits the disclosure-led empowerment of accountability claimants by fostering in them a political interrogation of the configurations of decision-making authority producing environmental harm. The power-effects here relate to influence over the design of disclosure-based governance and institutional choices over sustainability.

Scholarly accounts of the transparency-accountability nexus in sustainability governance engage at least implicitly, if selectively, with the hypotheses identified above, and are informed by different theoretical frameworks. The multi-dimensional theory of power developed by Lukes allows us to identify which aspects of power are addressed by this literature, distinguishing broadly between behavioural and non-behavioural views of power. Behavioural accounts focus on those aspects of power in decision-making that are accessible to empirical observation, as expressed by the political preferences and participation of individual actors: the locus of one-dimensional power, Lukes claims, is therefore the capacity of an actor to enact decisions (2005, pp.16-19). Two-dimensional power also relates to the preferences and capacities of individual actors, but names a separate nondecision-making power to prevent grievances being articulated politically or decisions being taken (Lukes, 2005, pp.20-25).

Principal agent and institutionalist perspectives on disclosure-based accountability claims within sustainability governance tend to focus on the exercise of one- and two-dimensional power, exploring the effects of information asymmetries as they impact on actor behaviour and decision-making. Reducing such asymmetries through information disclosure increases the communicative resources for affected parties to make answerability claims against a power-wielder (H1) and test their justifications (H2), making it more difficult for those held responsible to manipulate information purely for strategic self-interest (H3). Informed by information economics and rational choice analysis, principal-agent theory thus considers 
strategic interactions between parties subject to an accountability relationship in which the agent is answerable to, and sanctionable by, at least one principal. As Rosenberg (2017, p.14) argues, different patterns of accountability apply depending on the mix of public and private authority, but there is a shared propensity for agents to hide information in order to protect their interests. For example, research on greenwashing by firms has revealed that under governmental threats of mandatory disclosure, corporations selectively disclose positive sustainability information, misleading consumers who make green purchasing choices (Lyon \& Maxwell, 2011; Lyon \& Montgomery, 2015). In global sustainability governance, where accountability relationships stretch across overlapping institutions and international borders, the provision of sustainability information can also be skewed by principal-agent dynamics (Andonova, 2010; Rosenberg, 2017). From this theoretical stance increased transparency in governance can improve accountability for relevant sustainability impacts by reducing the capacity of the agent to produce selective, potentially misleading, information.

Rational choice analysis also gives rise to institutionalist perspectives on transparencyaccountability relationships in public and private governance for sustainability. These approaches consider power as a capacity of individual actors to achieve intended outcomes, as gauged from observed interactions and behavioural changes. Rational choice institutionalism treats institutions as rule-governed settings in which institutionalised disclosure can overcome barriers to cooperation amongst self-interested actors arising from the presence of uncertainty and economic disincentives to contribute to public (environmental) goods. Structured disclosure of data on environmental impacts allows in principle the identification and sanctioning of free-riding polluters, whether applied to corporations (Garcia et al., 2009; Bae et al., 2010) or states (Barrett, 2003, pp.269-91; Bosetti et al., 2013). Here the "power" of additional information for actors is an enhanced capacity to build trust through communication, reducing incentives not to cooperate. Broadly sharing the 
behaviourist assumptions of rational choice theory but drawing also on organisational theory, liberal institutionalism has, in its investigation of the transparency-accountability nexus in sustainability governance, moved beyond an early focus on environmental disclosure mechanisms enabled by public international law (e.g. treaty obligations between states to notify, consult and seek consent) to capture the complex dynamics of information disclosure associated with private and hybrid forms of governance at different scales (Bauhr \& Nasiritousi, 2012; Huang \& Yue, 2017; Pattberg, 2017). However, the analytical interest remains how the targeted disclosure of information can, through improved opportunities to evaluate and steer behaviour, facilitate more effective sustainability governance. Liberal institutionalism relaxes the strong utilitarian premises of rational choice theory when examining real-world contexts of sustainability governance by disclosure, paying greater methodological attention to decision settings and the two-dimensional power effects of agenda-setting and control.

Lukes' third-dimensional view of power overcomes what he claims are the limitations of a behavioural approach which, focused methodologically on the preferences of actors, sees power operate through decisions and observable conflicts. While observable behaviour may provide evidence for attributing the exercise of power - including for assessing the validity of Hypotheses 1-3 - for Lukes the third dimension of power illuminates a systemic capacity to advance certain interests, whether through the operation of social processes and institutional practices, or indeed individuals' decisions (2005, pp.25-29). Third-dimensional empowerment of accountability claimants, from the disclosure of sustainability information, is captured by Hypothesis 4: information disclosure is posited to empower these actors by fostering political interrogation of the configurations of decision-making authority producing environmental harm. Critical political economy and constructivism are leading theoretical approaches investigating third-dimensional power in sustainability governance. Their 
coverage of (dis)empowerment dwells on the embedding of disclosed information in material and linguistic contexts of power.

For critical political economy perspectives, power is grounded in the social structures and unequal relations of the global political economy (Newell, 2008). This situates sustainability governance in relation to economic globalisation and its systemic production of environmental harm, examining the growing spread of private authority, capitalist constraints on international regulation, and the political challenges raised by non-state actors. It opens analytical space for less observable aspects of power; notably, the political-economic forces and institutional biases that determine whether and how environmental sustainability issues are addressed (Newell, 2008, pp.523-24). The presence of such agenda controlling power within the transparency-accountability nexus for sustainability governance means acknowledging conditions under which information disclosure may, by its selectivity and framing, displace or dilute efforts to exercise politically meaningful accountability claims against those responsible for harmful practices. Examples include accountability disputes over the voluntary corporate reporting of sustainability information within the Global Reporting Initiative and Carbon Disclosure Project (Knox-Hayes \& Levy, 2014) and by the agricultural biotechnology industry (Clapp, 2008).

As argued by constructivist perspectives, the very processes of political contestation and negotiation over the nature of information - what is valid knowledge and who has epistemic authority - are constitutive of sustainability governance (Fischer, 2009, pp.168-88; Gupta et al., 2014). This insight focuses on the discursive power of transparency, including the conditions of possibility of disclosure-based empowerment through constituting, using and debating transparency (Vijge, 2018). Thus, the power effects of transparency turn less on reducing information asymmetries in order to produce more rational outcomes, than on whose information counts and is accorded primacy in collective choices (Gupta \& Mason, 
2014:10; Mason, 2008). Kramarz and Park (2016) press this constructivist argument further: transparency is pivotal to realising accountability in governance only insofar as it encompasses deliberative openness over, and interrogation of, the purposive choices made by authority holders in determining the design of governance processes; for these choices are constitutive of the full operating field of accountability - accountability for what, to whom and how. This involves, they claim, the necessary investigation of the biases of all wielders of governance authority, exposing how specific actors and interests are legitimated.

Critical political economy perspectives and constructivist theory are sceptical of the empowerment posited by Hypothesis 4, viewing instead in third-dimensional power a propensity by power-wielders to foreclose framings of sustainability that demand strong accountability for the production of environmental harm. The power-effects identified here are systemic and institutional, suggesting that foreclosing arises less from strategic efforts at agenda control and more the reproduction, through information disclosure, of dominant technical-managerial norms of sustainability. This idea of foreclosing is consistent with critiques of the idea of sustainability as a technology of governance, reproducing consent on the idea of sustainability as carving out, and legitimating, a "safe operating space" (Rockström et al., 2009) for global capitalism. These critiques identify a widespread naturalistic self-understanding of sustainability that displaces politically and economically situated understandings of “environmental” problems (Latour, 2004, pp.18-32; Swyngedouw, 2011). As Swyngedouw asserts, "there is nothing foundational in Nature that needs, demands, or requires sustaining” (2011, p.261). By its naturalistic generality, environmental sustainability is seen to mask the systemic concentrations of power that must be addressed to realise meaningful accountability for socio-ecological harm.

In the next section of the paper, I review recent scholarship on the functioning of information disclosure in sustainability governance, seeking to identify salient empirical findings on 
whether and how transparency furthers accountability, having regard to the hypotheses above on the empowerment of accountability claimants. While acknowledging the complexity and increasing hybridity of sustainability governance, the review distinguishes analytically between public and private sources of institutional authority.

\section{Public authority and sustainability disclosure}

As Kramarz and Park (2016, p.10) remark, public accountability is the default setting for discussions of responsibility and answerability for environmental harm because states remain the primary holders of governance authority. Principal-agent theory has been widely applied in political science to examine the public accountability of state institutions, probing the means by which bureaucracies are held to account by higher-order political and judicial actors, as well as the accountability of political representatives to their electorates.

Nevertheless, prevailing patterns of interest representation in national regulatory systems do not readily register sustainability values, notably the consideration of transboundary environmental degradation, intra- and inter-generational justice, and the protection of common-pool resources. There is also a marked discrepancy between the proliferation of multilateral environmental agreements and assessments of environmental sustainability marking continuing deterioration in climatic, ecological and biogeochemical systems (e.g. Steffen et al., 2015).

A key rationale, then, for the disclosure of sustainability-related information by public authority actors is to improve feedback on social and ecological effects, assuming that the reduction of information asymmetries between decision makers and affected parties allows a more effective communication of the sustainability concerns of the latter (H1) along with greater answerability (H2) and responsiveness (H3) from the former. However, research on 
transparency in global environmental governance finds that reductions in information asymmetry on sustainability effects are, by themselves, not sufficient to secure greater external accountability in governance (Ciplet et al., 2018; Gupta \& Mason, 2014), so there is a low evidential basis for confirming $\mathrm{H} 1$ and $\mathrm{H} 2$, which also makes problematic their causal link to disclosure-led steering (H3). Instead, research generally supports a finding in the transparency literature that the governance effects of disclosure on recipients and disclosers rely on the information resonating with their everyday decision making (Fung et al., 2007).

Research corroborating this "embeddedness" thesis covers a wide range of national political systems. As Florini and Jairaj (2014) observe in their cross-national survey of environmental transparency mechanisms, variations in capacity to comprehend and act on disclosed information are significant determinants of the procedural empowerment of information users. Even in advanced democratic states with mature civil societies and established freedom-of-information laws, how information is processed and presented for public use shapes its utility for accountability claim-making; as shown, for example, in US studies on the Toxic Releases Inventory (Bae et al., 2010) and the mandatory reporting of carbon emissions (Matisoff, 2013). Where statehood and/or democracy is limited, disclosure-based environmental regulation is hampered without sufficient administrative and legal support for public information users, as shown by research on Indonesia (Blackman et al. 2004), the Philippines (Lee et al, 2013) and Myanmar (Vijge, 2018). Moves towards increased environmental transparency in China, under open government information regulations, have generated public accountability deficits arising from incomplete disclosure obligations incentivising selective disclosure (greenwashing) from polluters (Huang \& Chen, 2015) - and undeveloped infrastructures for the interpretation and use of information. Interestingly, some civil society organisations and local state actors in China have created, or supported, alternative data platforms - e.g. the Pollution Information Transparency Initiative - to boost 
community representation of environmental interests and the answerability of polluters (Tian et al., 2016).

For public authority exercised internationally, it is necessary to distinguish between state-led disclosure to other states and state-led disclosure to civil society actors, though both have public accountability implications. Prior informed consent mechanisms operate in several multilateral environmental agreements, including treaties on the transfer of hazardous waste (Basel Convention), hazardous chemicals and pesticides (Rotterdam Convention), persistent organic pollutants (Stockholm Convention), and trade in genetically modified organisms (Cartagena Protocol). While the formal disclosure obligations are between states, there is also an assumption that increased information about the risks of products registers the interests of affected consumers (H1) and the answerability of producers (H2). Moreover, prior informed consent rules are seen as a vehicle of responsive sanctioning $(\mathrm{H} 3)$ insofar as producers are encouraged to reduce the risk-bearing effects caused by their products: however, this steering effect is restricted by the selectivity of coverage of sustainability effects covered by prior informed consent rules, which are often skewed by the economic interests of powerful market actors (Gupta \& Mason, 2014; Mitchell, 2011).

As Mitchell (2011, p.1886) notes, market pressure on responsible producers from those made aware of harmful environmental effects is only one means of disclosure-led sanctioning (see also next section). Transparency enacted by holders of public authority can also be used to signal the illegitimate behaviour of public and private actors as a form of a "naming and shaming" with reference to violated environmental norms. In this respect, the measuring, reporting and verification (MRV) systems being developed in various environmental treaty regimes may over time facilitate greater answerability (H2) and responsiveness (H3) of power-wielders. Protracted negotiations within the UN climate change regime on MRV systems for reducing emissions from forest-related activities (REDD+), and nationally 
determined contributions on emissions reductions under the 2015 Paris Agreement, attest in part to tensions between states over global public accountability for climate mitigation activities impinging on sovereign authority (Gupta et al., 2014; Winkler at al., 2017).

The 1998 Aarhus Convention stands out as a seminal environmental treaty for endowing civil society actors with procedural rights central to accountability claim-making, including information access and meaningful opportunities to participate in, and challenge, environment-related decision-making. This remains an important multilateral instrument, notable for a novel compliance mechanism open to civil society submissions on the enactment of Aarhus obligations by contracting states. At the same time, the treaty only applies to information held by government bodies: private enterprises are excluded from mandatory disclosure obligation, although a 2003 Protocol of Pollution and Transfer Registers facilitates the standardised publication, by administrative authorities, of pollution emissions reported by the owners or operators of relevant facilities. Research on the implementation of Aarhus information disclosure provisions reveals a dilution of their legal force due to the significant discretionary space allowed to parties in interpreting treaty obligations (Mason, 2014).

Sustainable development norms have entered the accountability metrics of international organisations, partly due to civil society advocacy. For example, Park (2010) shows how the interaction, over time, of World Bank actors and transnational environmentalist networks, created organisational recognition then endorsement in the Bank of norms of information disclosure and sustainable development. Bank dialogue with NGOs and the creation of an Inspection Panel to investigate breaches of social and environmental safeguards institutionalised a measure of external accountability: peoples facing actual or potential harm from a World Bank-funded project can request an investigation and justification for Bank actions (H2), with some evidence of project-specific and policy-level responses that have 
altered World Bank practices (H3) (World Bank Inspection Panel, 2009, pp.79-92). An evaluation by Ehresman and Stevis (2014) of the disclosure policy and sustainability framework of the International Finance Corporation - the World Bank institution charged with assisting private investment in developing countries - identifies reduced asymmetries in information on significant social and ecological impacts between sponsored corporations and affected communities (H1) and generally a greater onus on the former to justify their projects $(\mathrm{H} 2)$, but that, aside from certain projects applying to indigenous communities, there is no disclosure-responsive power for affected communities to steer or block a project (rejecting H3).

Accountability relationships become even more complex as international organisations engage in hybrid governance relationships with private sector actors. Within global governance, there are numerous collaborative partnerships for sustainable development between state and nonstate actors, including sustainability-relevant partnerships under the Global Environment Facility, the United Nations Fund for International Partnerships and the voluntary Type-II Partnerships set in play by the 2002 Johannesburg Summit of Sustainable Development (Andonova, 2010; Bäckstrand, 2008; 2012). Heralding in principle "horizontal" governance forms for which transparency features as a major guarantor of internal (partner) and external (public) accountability, partnerships for sustainable development typically commit to the discursive justification of sustainability effects posited by $\mathrm{H} 2$, yet often fall short. Bäckstrand observes such failings in the Johannesburg Partnerships: "Deliberative processes tend to be cosmetic and symbolic and are often added-on or serve to legitimize decisions already made" (2012, p.174).

Part of the accountability deficit arises, Bäckstrand claims, from the narrow governance role assumed by the Type-II Partnerships, focusing on rule implementation rather than rulemaking - a weakness compounded by a bias of representation and participation towards 
global Northern states, large developing countries, climate capitalists, professional NGOs and multilateral bureaucracies (2012, p.175). She observes a governance domain in which deliberation of sustainability information forecloses political interrogation of private and public authority configurations producing environmental harm (rejecting H4). This mirrors the argument of Kramarz and Park (2016) that forms of accountability which fail to engage with the design of governance goals and institutional capacities displace a wider reckoning of the constitution and effects of authority. Thus, accountability gains in the World Bank Group relating to social and environmental safeguards are offset against a structural imperative to invest in or underwrite development projects advancing capitalist modernisation and industrialisation (Park, 2010, pp.242). Similarly, Bracking's (2015) study of the Green Climate Fund - the principal UNFCCC funding mechanism for developing countries reveals how powerful states and carbon trading interests captured its governance agenda, displacing and disregarding as "overflows" the demands of civil society activists for greater external answerability (2015, pp.292-93). To be sure, the Green Climate Fund has a comprehensive information disclosure policy, which includes webcasting of Board meetings, though in practice such meetings are often closed off without public justification (Transparency International, 2017, p.20).

\section{Private authority and sustainability disclosure}

Over the past few decades, private authority holders and market-based transparency mechanisms have assumed a growing role in sustainability governance at multiple scales. Gupta and Mason (2016, p.83-84) identify marketisation and privatisation as major rationales driving the uptake of information disclosure in sustainability governance: the former refers to disclosure to facilitate the creation, functioning and expansion of markets for environmental 
good and services, while the latter denotes (selective) disclosure to augment private value creation as it relates to sustainability opportunities and constraints. While both public and private actors may employ or face information disclosure norms to further market-based social choices, the privatisation rationale implies the fuller colonisation by private authority of governance relating to the disclosure and use of sustainability information.

As noted above, principal-agent theory highlights incentives for selective disclosure by corporations to take advantage of asymmetric information over the sustainability effects of their products and production processes: this constitutes greenwashing insofar as the released information is misleading about wider sustainability losses (Huang \& Chen, 2015; Lyon \& Maxwell, 2011). H1 is affirmed, in contrast, insofar as enhanced disclosure improves market outcomes by boosting the scope and credibility of sustainability information transferred between relevant parties on external (third party) environmental costs. By signalling sustainability information as having economic value for a corporation, whether directly (e.g. demand for green products) or indirectly (e.g. reputational value, regulatory risks), disclosure assists consumers, shareholder and employees in holding producers to account for their market performance and social welfare impacts (Kramarz \& Park, 2016, p.14). Outside these contractual relationships, civil society actors also use information disclosure to pressure and reward businesses on their performance in accord with sustainability standards. The campaigning of NGOs and activist coalitions continues to be important here, but there has also been a growing governance role for certification and labelling programmes jointly run by civil society and industry actors, where transparency is directed to the traceability of particular commodity chains: key examples include environmental stewardship schemes, extractive industries and agricultural commodity roundtables (Auld \& Gulbrandsen, 2010; Schleifer, 2016; Vijge, 2018). 
The direct commensurability of economic values suggests a tangible measure in private authority-led governance of the power effects of sustainability disclosure, for sustainability values are expressed by market metrics such as relative pricing, investment flows and market share. To take a leading example, the institutional members of the Carbon Disclosure Project (CDP) hold over \$100 trillion in assets, making use of climate and environment data selfreported by thousands of companies in an annual questionnaire. CDP has significantly improved the ability of institutional investors to assess climate-related risks and increased the availability of information on the sustainability-related activities of individual companies, whose questionnaire responses are posted on the CDP website. However, there is, at best, a qualified acceptance of $\mathrm{H} 1$ and reasons to question disclosure-led accountability gains in public answerability $(\mathrm{H} 2)$ and responsiveness (H3) for climate change harm. Using CDP data to interrogate corporations is hindered by data comparability issues and, for civil society groups, a paywall behind which only corporate members have access to analytical software. There is also no evidence that the CDP has significantly affected plant-level carbon emissions or emissions intensity (Knox-Hayes \& Levy, 2014; Matisoff, 2013).

The commodification of climate transparency in the CDP mirrors the marketisation of greenhouse gas emissions information in carbon offset markets. Worth $€ 48.4$ billion in overall turnover in 2015 (Thomson Reuters, 2016, p.3), global carbon markets feature a wide variety of state-regulated emissions trading schemes within and outside the UN climate regime, alongside smaller markets in voluntary carbon offsets. Both the compliance and voluntary carbon markets reduce information deficits on climate liabilities for private actors, which may allow public discussions on climate risk - indirectly affirming H1. However, there are recurring problems over the credibility of these markets, largely due to their opacity and the growing privatisation of climate risk information. Even the UNFCCC emissions trading regime, with centralised accounting and verification oversight, has been compelled to 
enhance transparency of certified emissions reductions to address concerns over their economic integrity. In the voluntary carbon markets, the majority of transacted offsets are verified by independent third-party standards (Ecosystem Marketplace, 2016, p.3), but this has not prevented fraudulent manipulation of climate information. While they are not designed to deliver deliberative justifications from actors responsible for major carbon emissions (precluding any testing of $\mathrm{H} 2$ ), carbon markets can in principle serve a steering role by building financial accountability for climate change risk (H3): this remains largely unrealised when the level and uptake of carbon prices remain low.

There are impediments to public accountability claim-making in other major cases of disclosure-led governance focused on the sustainability performance of private actors. For example, the Global Reporting Initiative (GRI), a Dutch-based NGO, has developed the most widely used set of reporting guidelines for corporate sustainability, especially in the financial services and energy sectors. Not unlike the disclosure dynamics of the CDP, the analytical use of GRI information - with 34,000 open source sustainability reports available by 2016 (Global Reporting Initiative, 2016, p.25) - by accountancy firms and other commercial intermediaries has skewed GRI-related discourses of sustainability responsibility towards corporate managerial goals (Caron \& Turcotte, 2009). Civil society groups targeting specific sustainability losses have been frustrated by the lack of comparability and credibility of the self-reporting by companies (Dingwerth \& Eichinger, 2014; Knox Hayes \& Levy, 2014), which GRI has attempted to address with new global standards on sustainability (Global Reporting Initiative, 2016, pp.14-15).

With their product-specific terms of reference and stakeholder governance structures, environmental stewardship schemes arguably provide more meaningful procedures for the deliberative justification of sustainability claims by corporate members (Kramarz \& Park, 2016, p.4). Evidence supportive of $\mathrm{H} 2$ is available from the use of transparency in both the 
rule-making and auditing processes of the Forest Stewardship Council and Marine Stewardship Council, revealing a diverse range of nonstate actors discussing standards of environmental sustainability (Auld \& Gulbrandsen, 2014; Gulbrandsen \& Auld, 2016); and multi-stakeholder discourse on sustainability certification is also apparent in agricultural commodity roundtables, such as the Roundtable of Responsible Soy and the Roundtable on Sustainable Palm Oil (Schleifer, 2016). Gulbrandsen \& Auld (2016) caution, though, that nonstate certification schemes can face normative tensions between internal (organisational) accountability and external accountability to those affected by these programmes: in the case of the Marine Stewardship Council, they identify a growing deficit in external accountability gauged by environmental NGOs leaving the scheme. Within nonstate certification programmes responsive sanctioning $(\mathrm{H} 3)$ for breaches of performance standards operates internally according to mutually agreed rules on verification and enforcement. While it is not uncommon for product certificates to be refused or withdrawn, many NGOs and activist coalitions charge that the pressure to increase corporate uptake of these programmes has diluted their sustainability standards.

At the same time, private governance schemes for sustainability certification do not wholly foreclose interrogation of relevant systems of political-economic authority (H4). Auld et al. (2015) observe a logic of empowerment informing these programmes - "an explicit aim to redistribute power, control, and resources to marginalized actors in global supply chains" (p.111). To be sure, empowerment here means economic actors favoured by sustainability certification through, for example, marketing access and training programmes, and such programmes can act as barriers to entry for smaller producers These power distributive effects serve external (public) accountability norms only indirectly to the extent that they converge with third-party interests in preventing sustainability losses; and this overlap depends on their sectoral and geographical coverage. At least for agricultural commodity 
roundtables, evolving global supply chains and the growth of South-South trade have demonstrated how capitalism can bypass such certification practices (Schleifer, 2016). Nevertheless, sustainability disclosure in private governance has, alongside civil society campaigning, fed into the global growth of "fair business" norms. And in the last decade this has seen several transparency standards legally imposed on businesses over supply chain social and ecological risks; for example, mandatory due diligence requirements in the European Union and US on "conflict minerals" and illegally logged timber (Partzsch \& Vlaskamp, 2016).

\section{Conclusion}

The discussion above of institutional trajectories of sustainability disclosure featuring public and private authority is by no means exhaustive, but suggests provisional conclusions on the four hypotheses positing that information disclosure empowers affected parties making accountability claims against relevant decision-makers (Table 2). Accountability claimmaking is a dynamic, intersubjective chain of speech acts heavily conditioned by contexts of communication (e.g. the openness and inclusiveness of linguistic exchanges between decision-makers and affected publics). The theories reviewed above all have analytical value in revealing particular power-related effects of information disclosure, broadly corresponding to behavioural (principal agent theory, institutionalism) and non-behavioural (constructivism, critical political economy) understandings of power.

\begin{tabular}{|l|l|}
\hline H1 & $\begin{array}{l}\text { Outside deceptive disclosure (e.g. greenwashing), reducing information asymmetry } \\
\text { between a decision maker and affected parties tends to lower the information costs } \\
\text { of the latter making accountability claims (general validity for H1) }\end{array}$ \\
\hline
\end{tabular}




\begin{tabular}{|l|l|}
\hline H2 & $\begin{array}{l}\text { Information disclosure tends to enhance the capacity of accountability claimants to } \\
\text { evaluate justifications provided by the relevant power-wielder, though this is less } \\
\text { likely in contexts where sustainability information is marketised and/or privatised } \\
\text { (partial validity for H2) }\end{array}$ \\
\hline H3 & $\begin{array}{l}\text { There is limited evidence that information disclosure enhances the capacity of } \\
\text { accountability claimants to steer relevant power-wielders (H3 not supported) }\end{array}$ \\
\hline H4 & $\begin{array}{l}\text { There is limited evidence that disclosure of sustainability information fosters } \\
\text { political interrogation of the configurations of decision-making authority producing } \\
\text { environmental harm (H4 not supported) }\end{array}$ \\
\hline
\end{tabular}

Table 2: Key findings on hypotheses positing empowerment of accountability claimants arising directly from the disclosure of sustainability information

One- and two-dimensional power applies to vectors of empowerment where information disclosure causes behavioural change in the governance relations between power-wielders and affected parties, as related to coalescent layers of accountability - communication of the accountability claims of affected parties (H1), furthering thereby the answerability (H2) and responsiveness (H3) of decision makers. Principal agent and institutionalist research suggests that, outside greenwashing and other forms of deception, information asymmetry is likely to be reduced through environmental disclosure by decision makers, with evidence that the preferences (interests) of affected parties are more effectively registered (H1). There is some indication that public disclosure of sustainability effects increases the answerability of decision makers to affected parties (H2): this discursive empowerment can be observed in governance forms featuring both holders of public authority (e.g. international treaties with MRV systems, World Bank Group) and private authority (e.g. environmental stewardship 
schemes), though where the release of sustainability information is significantly shaped by marketisation and privatisation logics (e.g. GRI, CDP), there is countervailing (twodimensional) nondecision-making over economic development pathways.

While information released under sustainability disclosure schemes is often used by NGOs and other civil society actors to raise demands for answerability, there is limited evidence supporting H3 - that disclosure empowers accountability claimants by enhancing their capacity to steer relevant power-wielders. Responsive sanctioning by those subject to governance decisions tends not to be a formal feature of sustainability disclosure initiatives or is defined in narrow procedural terms (e.g. prior informed consent). For public sustainability governance, this reflects a preference for disclosure as an end in itself, detached from redress against holders of authority responsible for harm; and while sanctioning mechanisms do feature in some examples of private sustainability governance, these are more to do with protecting the club good benefits of participating members (e.g. environmental stewardship schemes, voluntary carbon disclosure) than strengthening environmental accountability to affected actors.

Focusing on vectors of disclosure-led empowerment manifest in observable behaviour may miss third-dimensional power effects arising from taken-for-granted configurations of decision-making authority. The theoretical utility of critical political economy and constructivist approaches is in providing insights on this aspect of power as it relates to the disclosure of sustainability information. There is some evidence for this type of disclosureled empowerment (H4) where there are overlapping sustainability interests between affected parties and private governance initiatives, as noted by institutionalist research on environmental stewardship schemes (Auld et al., 2015). However, a recurrent finding of critical political economy and constructivist work is that disclosure of sustainability information often disempowers_accountability claimants by foreclosing political interrogation 
of the configurations of authority producing environmental harm. Sharing the critical intent informing Luke's (2005) notion of three-dimensional power, the theoretical claim here invites political analysis on how sustainability information permeates, and reproduces, a dominant matrix of market liberal dispositions which frame environmental accountability as the domain of private choices and individual responsibility. Relevant research cited above featured cases in which sustainability disclosure diluted accountability on socio-ecological harm by displacing justice-oriented positions (e.g. UNFCCC Green Climate Fund), not challenging organisational imperatives inimical to sustainability (e.g. World Bank Group), and skewing discourses of sustainability reporting towards corporate managerialism (e.g. CDP, GRI).

There are analytical challenges in justifying relevant counterfactuals for evaluating the thirddimensional power to mislead, and identifying what Lukes calls the "real interests" of those dominated (2005, pp.148-50). These challenges are compounded for sustainability interests, where respect for global ecological limits calls for system-wide responsiveness exceeding the governance contribution of current mechanisms for disclosure-led environmental accountability. Moving beyond the focus in this paper on different vectors of disclosure-led empowerment, further research could investigate whether multiple, converging forms of transparency can build social learning on sustainability goals. Useful benchmarks here are ideas of meaningful discussion and political negotiation on environmental sustainability as determined by affected communities (cf. Norton, 2005, pp. 297-99).

\section{References}

Andonova, L. B. (2010). Public-private partnerships for the Earth: Politics and patterns of hybrid authority in the multilateral system. Global Environmental Politics, 10(2), 25-53. doi: 10.1162/glep.2010.10.2.25. 
Auld, G. \& Gulbrandsen, L. H. (2010). Transparency in nonstate certification: Consequences for accountability and legitimacy. Global Environmental Politics, 10(3), 97-119. doi: 10.1162/GLEP_a_00016.

Auld, G., Renckens, S., \& Cashore, B. (2015). Transnational private governance between the logics of empowerment and control. Regulation \& Governance, 9, 108-124. doi: 10.1111/rego.12075.

Bäckstrand. K. (2008). Accountability of networked climate governance: The rise of transnational climate partnerships. Global Environmental Politics, 8(3), 74-102. doi: 10.1162/glep.2008.8.3.74.

Bäckstrand, K. (2012). Are partnerships for sustainable development democratic and legitimate? In P. Pattberg, F. Biermann, S. Chan, \& A. Mert (Eds.), Partnerships for sustainable development: Emergence, influence and legitimacy (pp. 165-182). Cheltenham: Edward Elgar.

Bae, H., Wilcoxen, P., \& Popp, D. (2010). Information disclosure policy: Do state data processing efforts help more than the information disclosure itself? Journal of Policy Analysis and Management, 29, 163-182. doi: 10.1002/pam.20483.

Barrett, S. (2003). Environment and statecraft: The strategy of environmental treaty-making. Oxford: Oxford University Press.

Bauhr, M., \& Nasiritousi, N. (2012). Resisting transparency: Corruption, legitimacy and the quality of global environmental politics. Global Environmental Politics, 12(4):9-29. doi:10.1162/GLEP_a_00137.

Biermann, F. (2014). Earth system governance: World politics in the Anthropocene. Cambridge, MA: MIT Press. 
Blackman, A., Afsah S., \& Ratunanda, D. (2004). How do public disclosure control programs work? Evidence from Indonesia. Human Ecology Review 11, 235-246.

Bosetti, V., Carrao, C., De Cian, E., \& Mosetti, E. (2013). Incentives and stability in international climate coalitions: an integrated assessment. Energy Policy 55, 44-56. doi.org/10.1016/j.enpol.2012.12.035.

Bracking, S. (2015). The anti-politics of climate finance: The creation and performativity of the Green Climate Fund. Antipode, 47, 281-302. doi: 10.1111/anti.12123.

Caron, M.-A. \& Turcotte, M.-F. B. (2009) Path dependence and path creation: Framing the extra- financial information market for a sustainable trajectory", Accounting, Auditing \& Accountability Journal, 22, 272-297. doi: 10.1108/09513570910933979.

Ciplet, D., Adams, K. M., Weikmans, R., \& Timmons Roberts, J. (2018). The transformative capacity of transparency in global environmental governance. Global Environmental Politics, 18, 130-150. doi: 10.1162/glep_a_00472.

Clapp, J. (2008). Illegal GMO releases and corporate responsibility: Questioning the effectiveness of voluntary measures. Ecological Economics, 66, 348-358. doi: 10.1016/j.ecolecon.2007.09.006.

Dingwerth, K. \& Eichinger, M. (2010). Tamed transparency: How information disclosure under the Global Reporting Initiative fails to empower. Global Environmental Politics 10(3), 74-96. doi: 10.1162/GLEP_a_00015.

Ecosystem Marketplace (2016). Raising ambition: State of the voluntary carbon markets. Washington, DC: Forest Trends.

Ehresman, T. \& Stevis, D. (2014). Transparency and environmental equity: The International Finance Corporation's disclosure practices. In A. Gupta and M. Mason (Eds.), Transparency 
and global environmental governance: Critical perspectives (pp. 297-320). Cambridge, MA: MIT Press.

Fischer, F. (2009). Democracy and expertise. Oxford: Oxford University Press.

Florini, A. (2007). Introduction: the battle over transparency. In A. Florini (Ed.), The right to know: Transparency for an open world (pp. 1-16). New York: Columbia University Press.

Florini, A. and B. Jairaj (2014). The national context for transparency-based global environmental governance. In A. Gupta and M. Mason (Eds.), Transparency and global environmental governance: Critical perspectives (pp. 61-80). Cambridge, MA: MIT Press.

Fung, A., Graham, M., \& Weil, D. (2007). Full disclosure: The perils and promise of transparency. New York: Cambridge University Press.

García, J. H., Afsah S., \& Sterner, T. (2009). What firms are more sensitive to public disclosure schemes for pollution control? Evidence from Indonesia's PROPER program. Environmental and Resource Economics, 42,151-168. doi: 10.1007/s10640-008-9211-2.

Global Reporting Initiative (2016). Empowering sustainable decisions: GRI's annual report 2015-2016. Amsterdam: Global Reporting Initiative.

Gordon, D. J. (2016). The politics of accountability in networked urban governance. Global Environmental Politics, 16(2), 82-100. doi: 10.1162/GLEP_a_00357.

Grant, R. W., \& Keohane, R. O. (2005). Accountability and abuses of power in world politics. American Political Science Review, 99, 29-43. doi: 10.1017/S0003055405051476.

Gulbrandsen, L. H., \& Auld, G. (2016). Contested accountability logics in evolving nonstate certification for fisheries sustainability. Global Environmental Politics, 16(2), 42-60. doi: 10.1162/GLEP_a_00353. 
Gupta, A. (2008). Transparency under scrutiny: Information disclosure in global environmental governance. Global Environmental Politics, 8(2), 1-7. doi: 10.1162/glep.2008.8.2.1.

Gupta, A., \& Mason, M. (2014). A transparency turn in global environmental governance. In A. Gupta \& M. Mason (Eds.), Transparency and global environmental governance: Critical perspectives (pp. 3-38). Cambridge, MA: MIT Press.

Gupta, A., \& Mason, M. (2016). Disclosing or obscuring? The politics of transparency in global climate governance. Current Opinion in Environmental Sustainability, 18, 82-90. doi: 10.1016/j.cosust.2015.11.004.

Gupta, A., Vijge, M. J., Turnhout , E. \& Pistorius T. (2014). Making REDD+ transparent: The politics of measuring, reporting and verification systems. In A. Gupta \& M. Mason (Eds.), Transparency and global environmental governance: Critical perspectives (pp. 181201). Cambridge, MA: MIT Press.

Habermas, J. (1998). On the pragmatics of communication. Cambridge, MA: Polity Press.

Haufler, V. (2010). Disclosure as governance: The Extractive Industries Transparency Initiative and resource management in the developing world. Global Environmental Politics, 10(3), 53-73. doi: 10.1162/GLEP_a_00014.

Huang, R., \&, Chen, D. (2015), Does environmental information disclosure benefit waste discharge reduction? Evidence from China. Journal of Business Ethics, 129, 535-552. doi: 10.1007/s10551-014-2173-0.

Huang, T., \& Yue, Q. (2017). A borrowed cloak: The institutional bottlenecks to legislating environmental information disclosure by Chinese listed companies. Journal of Environmental Law, 29, 445-473. doi: 10.1093/jel/eqx019. 
Knox-Hayes, J., \& Levy, D. (2014). The political economy of governance by disclosure: Carbon disclosure and nonfinancial reporting as contested fields of governance. In A. Gupta \& M. Mason (Eds.), Transparency and global environmental governance: Critical perspectives (pp. 205-223). Cambridge, MA: MIT Press.

Kraft, M.E., M. Stephan. M., \& Abel, T. D. (2011). Coming clean: Information disclosure and environmental performance. Cambridge, MA: MIT Press.

Kramarz, T., \& Park, S. (2016). Accountability in global environmental governance: A meaningful tool for action? Global Environmental Politics, 16(2), 1-21. doi: 10.1162/GLEP_a_00349.

Latour, B. (2004). Politics of nature. Cambridge, MA: Harvard University Press.

Lee, E., Lejano, R. P., \& Connelly, R. J. (2013). Regulation-by-information in areas of limited statehood: Lessons from the Philippines' environmental regulation. Regulation \& Governance,7, 387-405. doi:10.1111/rego.12013.

Lukes, S. (2005) Power: A radical view, second edition. Basingstoke: Palgrave Macmillan. Lyon, T., \& J. Maxwell, J. (2011). Greenwash: Corporate environmental disclosure under threat of audit. Journal of Economics and Management Strategy, 20, 3-41. doi: 10.1111/j.1530-9134.2010.00282.x.

Lyon, T., \& Montgomery, A. W. (2015) The means and ends of greenwash. Organization and Environment, 28, 223-49. doi: 10.1177/1086026615575332.

Mason, M. (2005). The new accountability: Environmental responsibility across borders. London: Earthscan. 
Mason, M. (2008). Transparency for whom? Information disclosure and power in global environmental governance. Global Environmental Politics, 8, 8-13. doi: $\underline{10.1162 / g l e p .2008 .8 .2 .8}$

Mason, M. (2014). So far but no further? Transparency and disclosure in the Aarhus Convention. In A. Gupta \& M. Mason (Eds.), Transparency and global environmental governance: Critical perspectives (pp. 83-105). Cambridge, MA: MIT Press.

Matisoff, D. C. (2013). Different rays of sunlight: Understanding information disclosure and carbon transparency. Energy Policy, 55, 579-592. doi: 10.1016/j.enpol.2012.12.049.

Mitchell, R. B. (2011). Transparency for governance: The mechanisms and effectiveness of disclosure-based and education-based transparency policies. Ecological Economics, 70, 1882-1890. doi: 10.10161j.ecolecon.2011.03.006.

Mol, A. P. J. (2008). Environmental reform in the information age: The contours of informational governance. Cambridge: Cambridge University Press.

Newell, P. (2008). The political economy of global environmental governance. Review of International Studies, 34, 507-29. doi: 10.1017/S0260210508008140.

Norton, B. G. (2005). Sustainability: A philosophy of adaptive management. Chicago: University of Chicago Press.

Park, S. (2010). World Bank Group interactions with environmentalists: Changing international organisation identities, London: Manchester University Press.

Partzsch, L., \& Vlaskamp, M. C. (2016). Mandatory due diligence for 'conflict minerals' and illegally logged timber: Emergence and cascade of a new norm on foreign accountability. The Extractive Industries and Society 3, 978-986. doi: 10.1016/j.exis.2016.07.003. 
Pattberg, P. (2017). The emergence of carbon disclosure: Exploring the role of governance entrepreneurs. Environment and Planning C: Politics and Space, 35, 1437-1455.

Rockström, J., Steffen, W., Noone’ K, Persson, Å., Stuart Chapin, III, F., Lambin, E. F., ... Foley, J. A. (2009). A safe operating space for humanity. Nature, 461, 472-475. doi: $10.1038 / 461472 \mathrm{a}$.

Rosenberg, J. (2017). More than a question of agency: Privatized project implementation, accountabilities, and global environmental governance. Review of Policy Research, 34, 1030. doi: 10.1111/ropr.12209.

Schleifer, P. (2016). Private governance undermined: India and the Roundtable on Sustainable Palm Oil. Global Environmental Politics, 16(1), 38-58. doi: 10.1162/GLEP_a_00335.

Steffen, W., Richardson, K., Rockström, J., Cornell, S. E., Fetzer, I., Bennett, E. M., ... Sörlin, S. (2015). Planetary boundaries: Guiding human development on a changing planet. Science 347, 736. doi: 10.1126/science.1259855.

Stephan, M. (2002). Environmental information disclosure programmes: They work but why? Social Science Quarterly, 83, 190-381. doi: 10.1111/1540-6237.00078.

Swyngedouw, E. (2011). Depoliticized environments: The end of nature, climate change and the post-political condition. Royal Institute of Philosophy Supplement, 69, 253-274. doi: 10.1017/S1358246111000300.

Tian, X.-L., Guo, Q-G., Han, C., \& Ahmad, N. (2016). Different extent of environmental information disclosure across Chinese cities: Contributing factors and correlation with local pollution. Global Environmental Change, 39, 244-257. doi:

10.1016/j.gloenvcha.2016.05.014. 
Thomson Reuters (2016). Carbon market monitor: America to the rescue. Oslo: Thomson Reuters.

Transparency International (2017). A tale of four funds: Best practices of multilateral trust funds in safe-guarding climate finance from corruption and waste. Berlin: Transparency International.

Vijge, M. J. (2018). The (dis)empowering effects of transparency beyond information disclosure: The Extractive Industries Transparency Initiative in Myanmar. Global Environmental Politics, 18, 13-32.doi: 10.1162/GLEP_a_00442

Winkler, H., Mantlana, B., \& Letete, T. (2017). Transparency of action and support in the Paris Agreement. Climate Policy, published online 10 April, 2017 doi:

10.1080/14693062.2017.1302918.

World Bank Inspection Panel (2009). Accountability at the World Bank: The Inspection Panel at 15 Years. Washington: IBRD/World Bank. 